\title{
Understanding labour politics in an age of precarity
}

\author{
Sian Lazar $^{1} \cdot$ Andrew Sanchez ${ }^{1}$
}

Published online: 23 February 2019

(C) The Author(s) 2019

\begin{abstract}
The introductory essay to this collection examines the possibilities that work-based collective organisation affords for transformative politics under precarity. We begin from the premise that precarity is experienced in different ways in the Global North and South, among stable workers and in 'informal' work. Recent scholarship has explored the relationship between precariousness in life and labour, but has paid less attention to labour relations. Contrary to some dominant theories of 'the precariat', we suggest that precarious workers are not always anomic and lacking in work-based political identity, but nor are they straightforwardly a 'class in the making'. The papers in this volume show that there are multiple ways that people organise collectively to challenge and improve their conditions of work, from traditional trade unions, cooperatives, and union-like associations. All have different ramifications for politics and understandings of class composition, and of how informal and precarious economies are likely to develop in the future.
\end{abstract}

Keywords Capitalism $\cdot$ Class $\cdot$ Labour $\cdot$ Precarity $\cdot$ Social movements $\cdot$ Trade unions

\section{Introduction}

Although precarity has been the subject of much interest in recent scholarship, less sustained attention has been paid to the reconfigurations of labour politics that attend such conditions. This special issue interrogates how the precarisation of labour affects the form and possibilities of contemporary work-based politics. It does so in reference to ethnographic research conducted in a wide variety of contexts that considers how the experience of precarity varies between the Global North and the Global South, and between different sectors of the economy.

Sian Lazar

s1360@cam.ac.uk

Andrew Sanchez

as2672@cam.ac.uk

1 Department of Social Anthropology, University of Cambridge, Free School Lane, Cambridge CB2 3RF, UK 
We believe that a focus upon labour politics is timely, since the precarisation of labour challenges many existing understandings about the nature of class and political struggle.

In this collection of eight papers, we suggest that precarious workers are not always anomic and lacking in work-based political identity (see Standing 2011), but nor are they straightforwardly a 'class in the making'. We examine the different constellations of labour politics, showing the variety in strategies, histories, and experiences in cases from South Asia, East Asia, Central Asia, the Middle East, Europe, and Latin America. By documenting the variety of contexts and histories of precarity across the globe, and connecting that to an appreciation of the relation between experience and political action, we show how labour politics are embedded in daily life and what that means for living with precarity. The papers in this issue incorporate ethnographic analyses of topics as varied as risk, resistance, aspiration, cynicism, bureaucracy, security, morality, and economy, and aim to contribute a more nuanced understanding of how precarity is constituted in different social settings.

In this introduction, we define three core areas that our papers speak to: the conceptual meanings of precarity, the relationship between social movements and labour, and the implications that contemporary precarisation has for understandings of class.

\section{The meanings of precarity}

The concept of precarity first emerged in French sociology and economics. In the concept's initial articulations during the 1970 s, précarité described a social condition linked to poverty, that only later came to refer to 'new' employment forms of precarious work outside of the classic Fordist version of full-time permanent contracts (Barbier 2002). From the early 2000s onwards, the idea of precarisation emerged, understood as a societal process of increasingly insecure employment and generalised uncertainty. This analysis can be mapped to contemporaneous European literature on social exclusion (Barbier 2002), but also, as Munck argues (Munck 2013), to debates further afield about the allied concepts of marginality and the informal sector (cf Bauman 2013; Day et al. 1999; De Genova 2002; Sassen 2014). From there, précarité became a 'political proposition'(Casas-Cortès 2017), and with its linked notion of the precariat was used by European activists in the EuroMayDay protests of 2001-6, to describe the condition of labour after the roll back of the welfare state, with a special focus on the proliferation of immaterial and intermittent labour, the mobility of labour, and the ways that capital extracts value from labour well beyond the wage relation (Casas-Cortès 2017).

In an article published in 2008, Neilson and Rossiter claimed that this movement of 'the precariat' ran out of steam politically, mostly because of its grounding in a specifically Northern European sense of loss of the Fordist promise of secure employment with allied benefits and the safety net of the welfare state for those who fell out of that social contract (2008). They are not alone in pointing out that the Fordist heyday of the 1940s-1970s (the socalled trentes glorieuses in France) must be seen as the exception rather than the norm even in Europe (e.g. Piketty 2014). As the EuroMayDay protests lost their momentum, and ultimately transformed into the Indignados, $15 \mathrm{M}$, Occupy, nuits debouts, and other movements, academic interest in precarity grew (Neilson and Rossiter 2008). This was prompted especially by the intervention of Guy Standing (2011), who drew on activist analyses to develop his version of the precariat and propose it as 'the new dangerous class', a political subject akin to the proletariat or multitude (Hardt and Negri 2005), characterised by lack of labour security including stable work-based identity. 
Standing argued that the precariat is 'a class-in-the-making', but not yet a class-for-itself; and that its members display 'anomie, anger, anxiety, and alienation' in the face of contemporary politics. His argument provoked critiques from those who disagreed with the claim that the precariat was a social class (Breman 2013; Munck 2013), even if the phenomena did describe a series of contemporary labour regimes in specific places (Breman 2013). Critics also noted that the precariat concept did not have quite the global applicability that Standing claimed, precisely because of its reliance upon a European model of labour norms. As Munck (2013) argues, 'from a Southern perspective, work has always-already been precarious', a point that we return to below. Standing (2014) responded to these claims, by specifying that not all workers in the 'informal sector' could be considered part of the precariat. However, in doing so, he nonetheless demonstrated that the imagined constituent of the precariat concept was indeed mostly the European subject of the précarité social movements; the highly educated young people denied the future that they had come to expect based on their parents' experience of the Fordist social compact. Still, the naming of precarious work as a political problem in this way is nonetheless fruitful for a consideration of the relation between global political economy, everyday life, South-North and South-South comparisons, and the constitution of political subjects, as the articles in this special issue show.

Meanwhile, Judith Butler's (2016) interventions in the French debate about précarité took the concept in a slightly different direction to that proposed by scholars of labour and economy. She argued that the precariousness of life 'implies living socially', that is to say depending on others and having obligations to them, while precarity is the political process of differentially inducing precariousness, especially in the form of vulnerability to state violence. Thus, 'precarity designates that politically induced condition in which certain populations suffer from failing social and economic networks of support and become differentially exposed to injury, violence, and death.' This is a kind of necropolitics (Mbembe 2003) where some populations are made more grievable than others. The vulnerable subjects that Butler has in mind range from the victims of the US-led 'War on Terror', to Palestinians in Gaza, and transgender victims of violence on the streets of Brazil.

Mediating between these potentially conflictual approaches, Anne Allison's work brought the two conceptions of precarity together, by linking increased instability of labour with anxieties about a 'relationless society' in contemporary Japan, to describe the condition of irregular workers as one of 'a state of desperation, of panic over debt collectors and rent, a life lived on the edge.' (2013: 6). The effects of neoliberal globalism have led, she argues, to a psychic condition of insecurity, uncertainty, and the failure of everyday life, exemplified in stories of people left to starve to death because they had no work and no one to check up on them. Such an approach echoes earlier attention in North American sociology to the relationship between urban marginality, bodily vulnerability (Klinenberg 2001), and the psychology of 'desolation' (Wacquant 2010).

Both these conceptions of precariousness and precarity describe global processes, albeit largely from the perspective of the global North. They have in common an emphasis on secure waged labour for everyone as the object of desire, and its loss without the protection of the welfare state (or other kinds of social welfare) as a prompt for the anxiety that comes from uncertainty (Muehlebach and Shoshan 2012; Mole 2010). Yet in large parts of the global South, neither the welfare state nor secure waged labour has ever been widespread enough to constitute such normative objects of desire.

In their critiques of Standing, both Munck and Breman pointed out that work in the global South has 'always-already' been precarious (Breman 2013; Ferguson 2015; Munck 2013). 
This is a point recognised in the language of analyses of 'informal' economies from the early 1970s onwards (Hart 1973; Peattie 1987), or Michael Denning's (2010) concept of 'wageless life' to describe life in cities across post-colonial states (see also the discussion in Ferguson 2015). As Denning suggests, 'capitalism begins not with the offer of work but with the imperative to earn a living', and that happens in multiple ways; not all of which include a wage relation. People sell goods on the streets, stitch garments for piece rates, borrow money, live from cash or food transfers from governments and NGOs, and so on. Of course, they also make bricks, labour in others' fields, mine metals, carry goods, build offices, dig roads, clean houses, tend gardens, etc., for day rates; or live from the salary earned by the one member of their household with a government job (whether short term or permanent). So, their lives are not necessarily entirely wage-free, but nor are they characterised by the model of a secure male wage that could support a whole family - a model that was of course only available to a select few in the North anyway.

Denning's call to 'decentre wage labor in our conception of life under capitalism' (2010) is well phrased, but does echo a feminist argument that has been made since at least the 1970s. Multiple scholars and activists have pointed out the role of housework in the reproduction of life and labour power (Federici 2008). They argued that female labour in the house is necessary to produce and service workers for factories, offices, streets and so on; and as such, it subsidises the wages paid to the (male) workers, and therefore the profits for capital. Meanwhile dominant 'workerist' ideologies grant normative moral power to hegemonic forms of waged labour and the nuclear family (Weeks 2011). Making the payment for work-and working conditions themselves - as 'flexible' and precarious as possible has created a highly efficient regime of accumulation enforced by governments from colonial times, becoming even more acute since the 1980s under the latest phase of global neoliberalism. For example, structural adjustment programmes in sub-Saharan Africa and Latin America consolidated landholding in rural areas in the hands of agribusinesses, prompting mass migration to cities (Davis 2004; Federici 2012); once more or less settled in peripheral city neighbourhoods, workers became available to work for low pay and to invest their labour power in autoconstruction of their houses and neighbourhoods, and in caring for relatives in the absence of state social or health care provision, etc. Globally, deregulation has meant an expansion of the global labour supply, allowing capital to move where labour is cheapest, while national governments have enforced measures of labour flexibility that enable precarious conditionsfrom the suppression of unions and the right to strike, to the development of special economic zones, to the maintenance of migrant illegality and consequent vulnerability to exploitation (Breman 2013; de Genova 2005; Federici 2012; Schierup and Bak Jorgensen 2017).

In the midst of these global and national processes, ordinary people focus on making a living, or 'sustaining life across generations' in Narotsky and Besnier's terms (2014: S6). The strategies by which they do so include 'relations of trust and care, economies of affect, networks of reciprocity encompassing both tangible and intangible resources, and material and emotional transfers that are supported by moral obligations'. They often evade regulation, either deliberately or because they cannot be regulated, and they are focussed on 'how to make life worth living, ... [an] effort to make life'. Here, Narotsky and Besnier signal an analysis that focusses on people's creativity, and it is this sensibility that the articles in this issue bring to our analysis of the politics of precarious work. ${ }^{1}$

\footnotetext{
${ }^{1}$ It is important to note that that creativity can lead to exclusionary politics as well as to inclusive ones (Narotsky and Besnier 2014).
} 
We do so because most of the authors discussed so far in this section have taken a fairly bleak outlook on the political possibilities arising out of precarious work and life. Standing argues that the precariat, although potentially dangerous, has yet to fulfil that promise and is in general anomic and apolitical. The more cultural descriptions of precarity often describe a kind of paralysis induced by uncertainty and the challenges of survival (Allison 2013), or the overwhelming power of state violence against precarious populations (Butler 2016). Ferguson (2015) is more positive, but sees the only possible politics for those who can no longer get access to waged employment as one of state-led distribution of welfare. With few exceptions (Munck 2013; Waterman 1993), most scholars agree that traditional labour organisations cannot or will not represent precarious workers - in North or South. It seems that they do not speak to these kinds of workers, and even often exclude them to protect the high(er) wages of their constituency of labour aristocrats, as Parry argues for the case of the steel plant in Bhilai, India (Parry 2013).

Yet, the marginality debates of the 1970s had viewed the urban poor as apolitical in a similar fashion (Perlman 1976). However, that was fairly quickly critiqued as scholars soon highlighted the multiple political strategies of the urban poor albeit mostly ignoring labour politics (see the following for recent articulations of this approach Bayat 2015; Caldeira 2015; Maskovsky 2018). The urban poor were understood to engage in infrastructural or service politics, like campaigns for property legalisation, or neighbourhood utilities as well as just selfgovernment (Chatterjee 2006; Lazar 2008). Scholars recognised in particular women's political activities associated with social reproduction and urban living, like mothers clubs, communal kitchens, advocacy for urban services and utilities, etc.

But what do the men do (as workers and as residents of urban neighbourhoods)? And, what do the women do when they are workers? The vision of 'traditional organised labour' as irrelevant to the contemporary situation of precarious workers participates in the same kind of post-Fordist perspective characteristic of the precarity debate. It displays a nostalgia for a time when strong unions protected the wage relation, as if it were only those kinds of unions that can serve as the model for labour politics. In fact, as this special issue shows, there are multiple possibilities for a collective politics of labour, even in highly precarious situations. From 'traditional' unions reaching out to contract workers to other forms of collective association based on kinship, village of birth, or common workplace, precarious workers do collaborate to improve the conditions under which they make their living. Documenting the variety of these is one of the objectives of this collection.

\section{Social movements and labour}

Historians of Europe and the USA often privilege the labour movements of the late nineteenth and early twentieth centuries in their discussions of social movements (Tilly and Wood 2012). But, from the 1970s onwards, there has been a decline both in labour movements themselves and in academic discussion of them. The latter was replaced by work on social movements of different kinds, initially from within sociology. ${ }^{2}$ Anthropologists are carving out an approach to social movements that is distinct from the classical sociological one (Osterweil 2014), to the point that some draw a line between a set of sociological approaches that they characterise as 'utilitarian' (Juris 2014) and anthropological concerns of culture, practice, imaginaries,

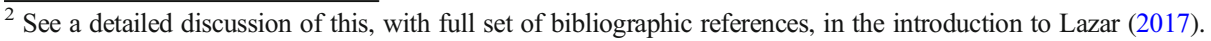


subjectivities, and so on. Dominant sociological approaches attempt to explain social movements, specifically their emergence and success (or failure), by resort to concepts like resource mobilisation and political opportunity structures, bringing in cultural questions through notions of framing. ${ }^{3}$ In contrast, anthropologists have focussed on the internal dynamics within movements, cultures of mobilisation, and the development of radical imaginaries of alternative worlds, subjectivities, and possibilities.

Current focus on radical alternative imaginaries is, to some extent, a reframing of older sociological debates, especially the New Social Movements literature (e.g. Melucci 1989; Touraine 1988). Beginning in the 1980s, scholars suggested that social movements had become more about identity than about the structural effects of class. The most potentially revolutionary protagonists were no longer the industrial proletariat but new actors mobilised on the basis of shared identity - ethnicity, gender, sexuality and so on (Escobar and Alvarez 1992). Newer terms like the multitude (Hardt and Negri 2005) and the precariat continue this search for new political subjects. By now, theorists have drawn back from some of the more extreme positions of earlier decades, which had appeared to downplay entirely the material aspects of social movement practices and demands in favour of cultural and social claims. From the late 1990s, scholars' gaze turned to globally networked anti-capitalist movements (e.g. Juris 2008; Maeckelbergh 2009), and recent analyses have stressed more explicitly social movements' economic concerns, often linked to the effects of globalisation as intrinsic to their cultural or identity-based interests (e.g. Nash 2005; Sawyer 2004).

Arturo Escobar (2009) describes the struggles of mobilised Afro-Colombian communities in terms of a 'political ecology' of place which enables them to create alternatives to dominant contemporary political formations, like liberal democracy. His concept of political ecology can also apply in an urban context. Over 30 years ago, Manuel Castells (1983) argued that the demands of urban social reproduction lead to neighbourhood-based mobilisation, like the women's movements mentioned above. Recent work in this vein emphasises claims to the right to the city (Harvey 2012). Anthropologists have explored these as expressions of the desire to live a good and collective life in the city, (Razsa and Kurnik 2012; Zigon 2014). While none of these place-based approaches deny the very real material effects of the capitalist processes that are being resisted; indeed, quite the opposite, they do often filter out class as an explicit category of identity that is the source of mobilisational energy. At one point, class seemed to be all there was for most theorists and actors, and the new social movement theories were an attempt to get away from that 'economic reductionism' (Lagalisse 2013: 132). But, the urge to seek alternatives to traditional notions of political movements like parties and trade unions meant that organised class-based resistance to capitalism slipped out of view in both scholarly work and political commentary. Yet, as discussed above, working class identities have not disappeared but have been reconfigured as increasingly precarious, and respatialised in parts of the globe where traditional forms of labour organisation are weak (Kalb 2015; Silver 2003). Further, new collective identities based on work have emerged in recent years, as movements of precarious or unemployed workers developed in countries like the ones to be studied here.

Union density has declined in many countries across the world ${ }^{4}$, a process exacerbated by the increasing freedom of capital to move where labour is cheaper and less organised (Silver 2003). Northern economies have been reconfigured away from more highly organised

\footnotetext{
${ }^{3}$ For detailed references, see Lazar (2017).

${ }^{4}$ See OECD figures on union density, from https://stats.oecd.org/ Retrieved 9/1/18.
} 
manufacturing sectors, to sectors where labour is less amenable to traditional trade union organising, both because workers are more precarious and because of the nature of the workplace. Many unions have not been able to appeal to these new kinds of workers, but that has not prevented workers from organising, or even from unionising. Even in the Global North, there has been some reinvigoration of unionism, with the importation of 'social movement unionism' from the South, also sometimes known as 'community unionism' (Collins 2012; Mollona 2009; Moody 1997; Waterman 1993). This is a political project that stretches beyond the workplace, where unions incorporate community based concerns in their activities, and COSATU in South Africa has been a pioneer of this (Desai 2003). In the Global South, we can find examples of invigorated unionism among workers as varied as those in the public sector in Argentina (Lazar 2017; see also Werbner 2014 on Botswana), home-based workers in India (Gartenburg 2017), farm workers and waste pickers in South Africa (Webster et al. 2017), garment workers in Guatemala and Bangladesh (Collins 2007; Prentice and De Neve 2017), and street vendors in Bolivia and India (Lazar 2008; Sinha 2018). New forms of autonomist unionism have emerged in response to failings of traditional unions (Ness 2014), such as the insurgent unionism in the $\mathrm{S}$ African platinum belt after the Marikana massacre (Sinwell and Mbatha 2016).

\section{Precarity and class struggle}

One of the dominant characteristics of late capitalism is its tendency to intensify conditions of precarity for people employed in traditionally stable environments. The effect of this process is to transform the essential character of formal employment and erode the fixity of previously existing work-based identities (Sanchez 2016). Significantly, the global casualization of labour has made indeterminacy the dominant condition of insecure work in many industries as permanent impermanence normalises ostensibly temporary contracts within regular structures of production. Employment conditions and forms may thus appear predictable and fixed through time, but are underpinned by profound insecurity, collapsing previously clear distinctions between regular and casual work (Sanchez 2018: 235).

Marxist thought has long regarded class as a dynamic historical process, as opposed to a discrete and bounded social object (Thompson 1991). However, the emphasis upon dynamic class struggle in Marxism has nonetheless relied upon paradoxical assumptions about an eventual certainty in subaltern imaginaries, viz., relations of production and the identity of one's class antagonists. Such epistemological clarity is the precondition of class-consciousness, and is understood to be the foundation of political struggle. However, the fracturing of workforces into finer fragments of precarious and secure employment renders epistemological certainty of this type less sustainable. This is why a close investigation of the tensions and contradictions of modern labour politics is vital for an understanding of how precarity works.

Beyond the industrial working classes that have traditionally attracted attention in studies of labour politics (Breman 2004; Gill 2007; Mills 1999; Mollona 2009; Nash 1979; Parry 2013; Turner 1999), insecure employment is today pervasive in global service sectors, care work, administration, creative industries, education, and consultancy, and is therefore impacting upon areas and communities that have not been previously characterised by precarity. The fact of creeping precarity requires an analytic response that is sensitive to the new contradictions and tensions that the development engenders. A class modelling of precarity therefore faces a number of challenges. 
First, such an approach must account for distinctions between persons who find themselves unexpectedly poor and vulnerable, and those for whom the experience is less novel. If it is true that social classes become political actors through recognition of their shared history, then, the very notion of a precariat has more discursive salience for communities of people who define their insecurity in temporal terms, distinguishing it from experiences of decline and the potential for progress. For declining Fordist labour forces precarisation is a new, collective experience that destabilises identity, family structure, and ways of life (Allison 2012: 349; Muehlebach 2011). By comparison, vast swathes of global labour do not regard precarity as new or as grounded in any type of collective labour history. This difference in perspectives suggests that the class modelling of the precariat concept is ill equipped to engage with the complex political life of insecure labour in modern workplaces.

Second, the erosion of job security is such a pervasive tendency in almost all areas of modern capitalism that precarisation may break down distinctions between permanently and temporarily employed persons within the same sector, as traditionally secure labour forces begin to share their homes and workplaces with precarious younger colleagues. Since these sections of the workforce may participate in the same household economy and share similar critical perspectives, the suggestion that they constitute distinct classes is not tenable in terms of either their economic position or political consciousness. It is for this reason that the papers in this collection pay close attention to the domestic lives, kinship and affinal networks of workers, since such a focus is essential for an understanding of how precarity functions and is experienced.

The papers in this collection engage critically with the concept of class consciousness, and attending forms of collective struggle, by asking how precarity relates to processes of dispossession, and whether precarisation has reconfigured traditional frontiers of solidarity. Our papers ask what kinds of strategies are available to precarious workers and their organisations, and how might wider forms of unrest relate to the politics of labour. In this regard, our authors are particularly sensitive to how the politics of neighbourhoods intersect with, and may even supplant, the politics of employment. We ask whether these new forms of struggle demand novel conceptual frameworks to understand them, and if the concept of class retains its analytic utility. The shifting ground of contemporary labour politics is explored through interrogations of how traditional trade unions relate to the precarisation of labour, and whether there is a mismatch between the needs of insecure workers and the institutional forms of unions themselves.

The articles in this collection consider the meanings of precarity through an expanded understanding of the term, which explores the relationship between poverty, state economic policy and vulnerability, alongside interrogations of how precarity is embodied through visceral experiences of violence, injury, and illness. We then consider whether precarisation entails popular disengagements from the institutional form of trade unionism itself. The collection begins with Patricia Matos' discussion of transformations of labour and state economic policy in contemporary Portugal, which approaches precarisation as an erosion of the familial and class structures through which ordinary people traditionally attained economic security. We then proceed to Patrick O'Hare's analysis of the formalisation of waste work in urban Uruguay. O'Hare shows how state efforts to shift waste pickers from landfills to ostensibly better conditions in recycling plants dispossess the poor from the common economic resource of public waste.

O'Hare's paper is followed by Elisabeth Schober's analysis of labour politics between the Korean and Filipino ship building industries. Schober explores how the increasing mobility of modern capital consolidates labour precarity, by demanding competition between transnational work forces and eroding class solidarity. In our next article, María Inés Fernández Álvarez 
draws upon research among street vendor cooperatives in Argentina, to explore the lived, historical relationship between corporality and precarity. Fernández Álvarez's shows how past experiences of precarity inform an imagined collective future for Argentine street vendors, which is ultimately integral to the formation of workers' unions. Christian Zlolniski then discusses the political lives of immigrant farm workers in Northern Mexico. Zlolniski shows how precarious farmworkers mobilise complex forms of individual, familial, and work-based action in their struggles against precarity, and demonstrates why analytic interrogations of such contexts must be sensitive to the relationship between labour and community mobilizations. In all three papers, trade unions are experienced as a complex, flawed but potentially valuable mobilisational form for the workers.

We then move to Hasan Ashraf \& Rebecca Prentice's discussion of trade union responses to factory disasters in the Bangladeshi garment industry. Ashraf and Prentice interrogate how trade unions' technocratic attention to the improvement of factory conditions, paradoxically fails to confront the broader structures of precarity itself. In our next paper, Dina Makram-Ebeid explores precarious labour politics in post-revolutionary Egypt, and illustrates how violence and the militarisation of everyday life in Cairo affects workers' experiences of precarity, and inspires popular critique of the terms of the revolution itself. In our final research paper, Eeva Kesküla \& Andrew Sanchez present a comparison of trade union politics in Kazakhstan and India, which explores how conservative and radical trade unions alike rationalise their work as a struggle against precarisation. Kesküla \& Sanchez explain why it is in the institutional nature of trade unions to betray such an affect. The collection closes with a critical afterword by Gavin Smith.

Acknowledgements This special issue began life as a workshop, Labour Politics in an Age of Precarity, held in April 2017. The editors would like to thank all those who participated, as well as the Centre for Research in the Arts, Social Sciences and Humanities at the University of Cambridge and the Fritz Thyssen Foundation for their support.

\section{Compliance with ethical standards}

The authors' research complies with the professional ethical standards of the Association of Social Anthropologists, the American Anthropological Association, and the ethical standards of the journal Dialectical Anthropology.

Conflicts of interest The authors declare that they have no conflicts of interest.

OpenAccess This article is distributed under the terms of the Creative Commons Attribution 4.0 International License (http://creativecommons.org/licenses/by/4.0/), which permits unrestricted use, distribution, and reproduction in any medium, provided you give appropriate credit to the original author(s) and the source, provide a link to the Creative Commons license, and indicate if changes were made.

Publisher's note Springer Nature remains neutral with regard to jurisdictional claims in published maps and institutional affiliations.

\section{References}

Allison, A. 2012. Ordinary refugees: Social Precarity and soul in 21st century Japan. Anthropological Quarterly 85 (2): 345-370. 
Allison, A. 2013. Precarious Japan. Durham: Duke University Press.

Barbier, J.C. 2002. A survey of the use of the term précarité in French economics and sociology. Document de Travail No 19. Retrieved from Paris.

Bauman, Z. 2013. Wasted lives: Modernity and its outcasts. London: Wiley.

Bayat, A. 2015. Plebians of the Arab Spring. Current Anthropology 56 (11): 33-43.

Breman, J. 2004. The making and unmaking of an industrial working class: Sliding down the labour hierarchy in Ahmedabad, India. New Delhi: Oxford University Press.

Breman, J. 2013. A bogus concept? New Left Review 84: 130-138.

Butler, J. 2016. Frames of war: When is life grievable? London: Verso Books.

Caldeira, T. 2015. Social movements, cultural production, and protests: São Paulo's shifting political landscape. Current Anthropology 56 (11): 126-136.

Casas-Cortès, M. 2017. A geneology of precarity: A toolbox for rearticulating fragmented social realities in and out of the workplace. In Politics of Precarity: Migrant Conditions, Struggles and Experiences, ed. C.-U. Schierup and M. Bak Jorgensen, 30-51. Brill.

Castells, M. 1983. The city and the grassroots : A cross-cultural theory of urban social movements. London: Edward Arnold.

Chatterjee, P. 2006. The politics of the governed: Reflections on popular politics in most of the world (Leonard Hastings Schoff Lectures). Columbia University press.

Collins, J. 2007. The rise of a global garment industry and the reimagination of worker solidarity. Critique of Anthropology 27 (4): 395-409.

Collins, J. 2012. Theorizing Wisconsin's 2011 protests: Community-based unionism confronts accumulation by dispossession. American Ethnologist 39 (1): 6-20.

Davis, M. 2004. Planet of slums. New Left Review 26.

Day, S., E. Papataxiarchis, and M. Stewart, eds. 1999. Lilies of the field: Marginal people who live for the moment. Boulder: Westview Press.

de Genova, N. 2002. Migrant 'illegality' and deportability in everyday life. Annual Review of Anthropology 31: $419-447$.

de Genova, N. 2005. Working the boundaries. In Race, space, and 'Illegality' in Mexican Chicago. Durham and London: Duke University Press.

Denning, M. 2010. Wageless life. New Left Review 66: 79-96.

Desai, A. 2003. Neoliberalism and resistance in South Africa. Monthly Review 54 (8).

Escobar, A. 2009. Territories of difference: Place, movements, life, 'Redes'. Durham: Duke University Press.

Escobar, A., and S.E. Alvarez, eds. 1992. The making of social movements in Latin America. Identity, strategy, and democracy. Boulder: Westview Press.

Federici, S. 2008. Precarious labor: A feminist viewpoint. Retrieved from https://inthemiddleofthewhirlwind. wordpress.com/precarious-labor-a-feminist-viewpoint/. Accessed 18 Feb 2019.

Federici, S. 2012. Revolution at point zero: Housework, reproduction, and feminist struggle. PM press.

Ferguson, J. 2015. Give a man a fish: Reflections on the new politics of distribution. Durham: Duke University Press.

Gartenburg, I. 2017. Organising vulnerable home-based workers in India. In Crossing the divide. Precarious work and the future of labour, ed. E. Webster, A. Britwum, and S. Bhowmik, 206-227. Pietermaritzburg: University of KwaZulu-Natal Press.

Gill, L. 2007. "Right there with you" Coca-Cola, Labor Restructuring and Political Violence in Colombia. Critique of Anthropology 27: 235-260.

Hardt, M., and A. Negri. 2005. Multitude. London: Hamish Hamilton.

Hart, K. 1973. Informal income opportunities and urban employment in Ghana. The Journal of Modern African Studies 11 (1): 61-89.

Harvey, D. 2012. Rebel cities: From the right to the city to the urban revolution. London: Verso.

Juris, J.S. 2008. Networking futures: The movements against corporate globalization, xviii, 378 p. Durham; London: Duke University Press.

Juris, J.S. 2014. Embodying protest: Culture and performance within social movements. In Conceptualizing culture in social movement research, ed. B. Baumgarten, P. Daphi, and P. Ullrich, 227-249. Houndmills: Palgrave Macmillan.

Kalb, D. 2015. Introduction: Class and the new anthropological holism. In Anthropologies of class, ed. J. Carrier and D. Kalb, 5-33. Cambridge: Cambridge University Press.

Klinenberg, E. 2001. Dying alone: The social production of urban isolation. Ethnography 2 (4): 501-531.

Lagalisse, E. 2013. Gossip as direct action. In Contesting publics. Feminism, activism, ethnography, ed. S. Cole and L. Phillips, 112-137. London: Pluto Press.

Lazar, S. 2008. El alto, rebel city: Self and citizenship in Andean Bolivia. Durham: Duke University Press. 
Lazar, S. 2017. The social life of politics: Ethics, kinship and activism in Argentine unions. Stanford: Stanford University Press.

Maeckelbergh, M. 2009. The will of the many. How the alterglobalisation movement is changing the face of democracy. London: Pluto Press.

Maskovsky, J. 2018. Reclaiming the streets: Black urban insurgency and antisocial security in twenty-firstcentury Philadelphia. Focaal 79: 39-53.

Mbembe, A. 2003. Necropolitics. Public Culture 15 (1): 11-40.

Melucci, A. 1989. Nomads of the present: Social movements and individual needs in contemporary society. Philadelphia: Temple University Press.

Mills, M.B. 1999. Enacting solidarity: Unions and migrant youth in Thailand. Critique of Anthropology 19: 175192.

Mole, N.J. 2010. Precarious subjects: Anticipating neoliberalism in northern Italy's workplace. American Anthropologist 112 (1): 38-53.

Mollona, M. 2009. Community unionism versus business unionism: The return of the moral economy in trade union studies. American Ethnologist 36 (4): 651-666.

Moody, K. 1997. Towards an international social-movement unionism. New Left Review, I/225(SeptemberOctober).

Muehlebach, A. 2011. On affective labor in post-Fordist Italy. Cultural Anthropology 26 (1): 59-82.

Muehlebach, A., and L. Shoshan. 2012. Post-Fordist affect: An introduction. Anthropological Quarterly 85 (2): 317-343.

Munck, R. 2013. The precariat: A view from the south. Third World Quarterly 34 (5): 747-762. https://doi. org/10.1080/01436597.2013.800751.

Narotsky, S., and N. Besnier. 2014. Crisis, value, and hope: Rethinking the economy: An introduction to WennerGren symposium supplement 9. Current Anthropology 55 (S9): S4-S16.

Nash, J. 1979. We eat the mines and the mines eat us: Dependency and exploitation in Bolivian tin mines. New York; Guildford: Columbia University Press.

Nash, J., ed. 2005. Social movements: An anthropological reader. Oxford: Blackwell.

Neilson, B., and N. Rossiter. 2008. Precarity as a political concept, or, Fordism as exception. Theory, Culture and Society 25 (7-8): 51-72.

Ness, I., ed. 2014. New forms of worker organization. The syndicalist and autonomist restroatin of class-struggle unionism. Oakland: PM Press.

Osterweil, M. 2014. Social movements. In A companion to urban anthropology, ed. D. Nonini, 470-485. Oxford: Wiley Blackwell.

Parry, J.P. 2013. The embourgeoisement of a proletarian vanguard? In Interrogating India's modernity: Democracy, identity and citizenship, ed. S. Jodhka. Delhi: Oxford University Press.

Peattie, L. 1987. An idea in good currency and how it grew: The informal sector. World Development 15 (7): 851-860.

Perlman, J. 1976. The myth of marginality. Urban poverty and politics in Rio de Janeiro. Berkeley: University of California Press.

Piketty, T. 2014. Capital in the 21st century. London.

Prentice, R., and G. De Neve. 2017. Unmaking the global sweatshop: Health and safety of the world's garment workers. University of Pennsylvania Press, Incorporated.

Razsa, M., and A. Kurnik. 2012. The occupy movement in Žižek's hometown: Direct democracy and a politics of becoming. American Ethnologist 39 (2): 238-258.

Sanchez, A. 2016. Criminal capital: Violence, corruption and class in industrial India. Oxford and New York: Routledge.

Sanchez, A. 2018. Relative precarity: Decline, hope and the politics of work. In Industrial Labor on the Margins of Capitalism: Precarity, Class and the Neoliberal Subject, ed. C. Hann and J.P. Parry, 218-240. New York: Berghahn Books.

Sassen, S. 2014. Expulsions. Brutality and complexity in the global economy. Cambridge and London: The Belknap Press of Harvard University Press.

Sawyer, S. 2004. Crude chronicles: Indigenous politics, multinational oil, and neoliberalism in Ecuador. Durham: Duke University Press.

Schierup, C.-U., and M. Bak Jorgensen, eds. 2017. Politics of precarity: migrant conditions, struggles and experiences. Brill.

Silver, B. 2003. Forces of labor. Workers' movements and globalization since 1870. Cambridge: Cambridge University Press.

Sinha, S. 2018. The struggle for space: Organising street vendors in India. In Redefined labour spaces. Organising work in post-liberalised India, ed. S. George and S. Sinha, 139-157. London: Routledge. 
Sinwell, L., and S. Mbatha. 2016. The spirit of Marikana: The rise of insurgent trade unionism in South Africa. Pluto Press.

Standing, G. 2011. The precariat: The new dangerous class. London: Bloomsbury Publishing.

Standing, G. 2014. Why the precariat is not a "bogus concept". Open democracy. Retrieved from https://www. opendemocracy.net/guy-standing/why-precariat-is-not-\%E2\%80\%9Cbogus-concept\%E2\%80\%9D. Accessed 18 Feb 2019.

Thompson, E.P. 1991 [1980]. The making of the English working class. Harmondsworth: Penguin.

Tilly, C., and L. Wood. 2012. Social movements, 1768-2012. Boulder: Paradigm Publishers.

Touraine, A. 1988. The return of the actor: Social theory in post-industrial society. Minneapolis: University of Minnesota Press.

Turner, C.L. 1999. Japanese workers in protest: An ethnography of consciousness and experience. Berkeley: University of California Press.

Wacquant, L. 2010. Urban desolation and symbolic denigration in the Hyperghetto. Social Psychology Quarterly 73 (3): 215-219.

Waterman, P. 1993. Social-movement unionism: A new union model for a new world order? Review (Fernand Braudel Center) 16 (3): 245-278.

Webster, E., A. Britwum, and S. Bhowmik, eds. 2017. Crossing the divide. Precarious work and the future of labour. Pietermaritzburg: University of KwaZulu-Natal Press.

Weeks, K. 2011. The problem with work: Feminism, Marxism, antiwork politics, and postwork imaginaries. Duke University press.

Werbner, P. 2014. The making of an African working class: Politics, law, and cultural protest in the manual workers union of Botswana. London: Pluto Press.

Zigon, J. 2014. An ethics of dwelling and a politics of world-building: A critical response to ordinary ethics. Journal of the Royal Anthropological Institute 20 (4): 746-764. 